Article

\title{
Using Multilevel Analysis to Examine the Relationship between Upper Secondary Students Internet Safety Awareness, Social Background and Academic Aspirations
}

\section{Ove Edvard Hatlevik * and Karoline Tømte}

Norwegian Center for ICT in Education, P.O. Box 1313 Vika, 0112 Oslo, Norway;

E-Mail: karoline.tomte@iktsenteret.no

* Author to whom correspondence should be addressed; E-Mail: ove.e.hatlevik@iktsenteret.no; Tel.: +47-854-19-000; Fax: +47-468-79-465.

External Editor: Roderick Graham

Received: 24 July 2014; in revised form: 18 October 2014 / Accepted: 21 October 2014 /

Published: 14 November 2014

\begin{abstract}
Since 2009, most Norwegian students in upper secondary have had access to their own personal computer at school. Hence, with the increased access to technology, the importance of online connectedness has increased for adolescents' social interaction and communication. It is, therefore, important to identify and understand the concept of Internet safety among upper secondary school students. A total of 4216 students from 238 classrooms in 23 upper secondary schools completed an Internet safety assessment. The aim of the study was to operationalize and measure Internet safety in a school context, and to further examine the factors predicting students' Internet safety awareness and responsibility. Our analysis revealed substantial variation in Internet safety awareness between schools, classrooms and students. Overall, the findings indicate that students' social backgrounds are determining for their development and understanding of Internet safety awareness.
\end{abstract}

Keywords: internet safety; multilevel analysis; upper secondary school; classical test theory; cultural capital; language integration; academic aspirations; reading proficiency 


\section{Introduction}

According to the European Commission [1], a high proportion of students in Norwegian upper secondary schools attend a school with a high level of infrastructure and connectedness. Since 2009, most upper secondary students have been assigned their own digital device from the county. Norwegian upper secondary schools are close to 1:1 access to technology, with students gaining a sense of personal ownership and responsibility over their own devices, an important aspect in developing digital competence. Schools expect students and teachers to use ICT (Information and communication technology) in teaching and learning at school [2]. However, with the increased access to technology, it is important that students develop Internet safety awareness as concerns privacy, copyright and safety issues.

When research is conducted on hierarchical or nested data from schools, for example students belonging to one classroom in one school, the researcher has to examine whether there is an effect of students being clustered. It is likely that students within the same classrooms could have some of the same characteristics, because they are taught and learn in the same environment. In order to take into account variation between clusters, i.e., classrooms or schools, techniques for multilevel analysis have been developed $[3,4]$. Multilevel analysis is a kind of regression analysis technique dealing with data where individuals are nested in clusters.

The aim of this paper is to identify Internet safety awareness among upper secondary school students in a school context, and to examine the relationship between upper secondary students' level of Internet safety awareness, social background and academic aspirations.

\section{Perspectives}

\subsection{Internet Safety}

The concept of Internet safety awareness derives from a European study [5,6] The concept emphasizes that students need to be aware of how their own or other people's actions can lead to serious consequences. The concept of Internet safety also stresses what students should consider when using the Internet, and what precautions should be taken. Ferrari [7] shows how the concept of safety covers protection of personal information, protection of data, protection of digital identity, security measures, safe and sustainable use of technology; all important aspects of Internet safety.

Livingstone [5] use three keywords - content, contact and conduct — to classify online risks for young people. Content implies that young people, as recipients, will be faced with spam, sponsorship, violent content, unwelcome sexual content and possibly racism. Contact implies that the young people, as participants, may be tracked, bullied or invited to meet strangers. Conduct implies that young people, as actors, conduct hacking, illegal downloading, bullying of others and creation of inappropriate material.

In this paper, the concept of Internet safety awareness is used in a broad way, dealing with young people as recipients of information, as participants interacting with others, and as actors who can influence, shape and create. Students not only need to be aware of what others can do, but they also need to be aware of how they can harm other people [5]. Internet safety has to do with the responsibility we have for ourselves, as well as for others. 


\subsection{Internet Safety as Part of Digital Competence}

According to Ferrari $[7,8]$ the concept of digital competence is used to describe what and how students are required to acquire, possess, learn and communicate by using technology. In our opinion, digital competence can be defined as the critical, responsible and efficient understanding and use of media, digital tools and digital resources in order to solve a case or a task, and in a more general sense, being a responsible citizen. This is a broader and more holistic perception of digital competence that goes beyond digital or technical skills [2].

When operationalizing digital competence in a European framework based on current research and practical attempts, Ferrari [7] recognizes safety, together with information, communication, content-creation and problem solving as five areas of digital competence. Historically, this has been done before. The "social, ethical and human issues" was one of six categories within a standard of technology developed by ISTE [9].

Several research papers $[7,9,10]$ mention privacy, safety or digital protection as important areas for developing a timely digital competence or skills. Binkley et al. present 10 skills that are important in the 21 st Century [10]. Among these, we find an emphasis on the need to develop personal and social responsibility. Calvani et al. measure digital competence among Italian students, and emphasize three areas related to Internet safety: staying safe online, respect on the net and understanding social and technological inequality [11]. Ferrari underpins the importance of safety operationalized as being able to protect devices, personal data, health and the environment [7].

Many elements of Internet Safety awareness, i.e., rules and legislation for copyright, privacy regulation or user terms, are relevant in schools that expect students to use computers or tablets as part of their learning activities. For example, students have to follow the rules and regulations for creating and sharing presentations and content according to copyright regulations, and they need to behave respectfully towards others during online activities. This means that Norwegian upper secondary students need to develop Internet safety awareness "by acquiring knowledge and good strategies for the use of the Internet" (p. 12) [12].

\subsection{Internet Safety as Part of the National Curriculum}

Since 2006, students' ability to use ICT has been one of five key competences in the Norwegian national curriculum [13-15]. This curriculum reform was an attempt to define and embed the use of ICT as a key element in the promotion and development of students' achievements across disciplines [15,16]. The reform has a more general track with less specific descriptions of how to use ICT, in additional to embedding the use of ICT as part of all subjects in primary and secondary school.

In the Norwegian curriculum, digital skills and competence is operationalized in four dimensions; Internet safety, the ability to acquire and process digital information, the ability to produce digital information and digital communication. The description of Internet safety in the curriculum, which is of relevance for this paper, refers to students' knowledge and understanding of how they or others behave online, and the responsibility they have for themselves and for others, for instance when it comes to issues such as copyright, privacy, and source evaluation. Internet safety includes both technical skills as 
how to change privacy settings and how to handle passwords, as well as more ethical issues of attitudes and values.

In order to be more specific about how Internet safety is described in the curriculum, some examples of competence aims from the secondary school level are presented [12,13].

(1) Example 1 from the Norwegian Subject Curriculum, Competence aims after Year 10, composite texts:

"The aims for the education are that the pupil shall be able to: elaborate on the fundamental principles of protecting personal privacy and copyright in connection with the publication and use of texts of others" (s.11) [17].

(2) Example 2 from the English Subject Curriculum, Competence aims after Year 10, written communication:

"The aims of the studies are to enable pupils to: be familiar with protection of personal privacy and copyright and choose and use content from different sources in a verifiable way" (s.9) [18].

(3) Example 3 from the Social Studies Curriculum, Competence aims after Year 10, geography:

"The aims for the education are that the pupil shall be able to: elaborate on one's own rights and consequences when working on the Internet and publishing one's own material" (s.8) [19].

These examples show how the "digital competence aims" are part of the subjects and how each competence aim can consist of different actions or activities. However, the schools are not given any instruction or template in order to achieve the competence aims, and therefore teachers and schools can adapt various approaches.

\subsection{Digital Divides among Students}

Students learn a lot by using technology during their leisure activities alone or together with other children [20,21]. However, Erstad questions whether students are able and willing to learn on their own about the use of technology, with the aim of learning school subjects and to achieve the competence aims of the curriculum [21]. In 2011, the European Commission asked European students from lower and upper secondary schools about their own proficiency in the use of technology [1]. The analysis showed variation in the students' perceptions about what they were able to conduct and carry out with the use of technology. It is, therefore, necessary to modify the picture of students as being motivated for and able to deal with digital challenges and use of technology when learning at school [22]. Even though students have extensive experience of using technology in informal settings, and are able to use devices and software for their own needs and purposes, they may still need guidance on how to transmit this experience to a learning context, how to gain knowledge of technology use for more formal learning, as well as how to behave responsibly online.

What about the "digital divide"? Warschauer [23] points out that the digital divide is not only about physical access to computers and connectivity, but also about whether people are able to make use of the systems, devices, software and content, in their learning at school. Pedró [24] describes how the term digital divide was first linked to access to technology, but as more and more people gain access to technology, the actual use of technology appears to be a new area where digital divides may occur. The so-called second wave of the digital divide is concerned with the ability to make use of technology 
in a valuable way. Instead of looking at the pc-ratio or the number of digital devices in each school, it seems more important to scrutinize how students actually use ICT for learning in school. The value and benefits of technology depend on how people make use of technology, much more so than on the technology itself.

\subsection{Social Background and Internet Safety}

The findings from the European Commission revealed variation in perceived competence and traces of digital diversity [1]. Similar findings are also reported from assessments of students' competence and achievements with technology. Studies show that the background of students' families influences students' abilities to use ICT in lower and upper secondary schools [11,20,25-27].

Findings from the European study EU kids online [28,29] show that children's social background can explain and predict the risk of children getting into dangerous or unpleasant situations online. Educational and economic disadvantage might enhance the likelihood of children being at risk online. The EU kids online study show that $27 \%$ of children from parents with lower secondary education or less report fewer online risks than average, but are more upset by risk, less skilled and less helped by parents to cope with risk [29]. Twenty-five per cent of children have parents who do not use the Internet. These children report fewer online risks but are more upset and have few skills to cope. Their parents lack confidence, they lack support from friends and family, and wish the school would guide them in being safe online. Seven per cent of children use the Internet less than once per week. Again, these children are reporting fewer risks, but more harm than the average. These children's digital skills are lowest of all, and although their parents do not think their children are well prepared to cope with the Internet, they do not plan to do more than other parents, to prepare their children [29]. It is important to note that risk may not necessarily lead to harm, and that being digitally competent may reduce the chances that risk will lead to harm.

The digital divide and the lack of digital inclusion is part of the digital age, and therefore still a threat to students $[21,22]$. Overall, international studies of ICT at school show how important it is to identify and understand the background and home environment of the students [20,25]. Asking questions about students' cultural capital, their language integration, their parents' educational level, or gathering information about the socio-economic status of the family, can accomplish this.

\subsection{Academic Aspirations}

Calvani et al. examined the digital competence performance in relation to which educational program students participate in [11]. They report that students from technological institutes had lower performance on a digital competence test compared with students attending institutes preparing them for academic studies. A similar finding was reported from previous Norwegian studies on upper secondary students [30,31], showing that the choice of study programs could explain digital competence. Internet safety can be seen as a part of digital competence [5,9], and one could expect different levels of Internet safety awareness among students from vocational study programs compared to students from general study programs. 


\subsection{Reading Proficiency}

Nowadays, many children are able to use smart phones, tablets or Interactive Whiteboards before they are able to read and understand text, because of the interface of these technologies, allowing the children to interact by pressing and dragging icons on a touch screen. However, reading proficiency can be significant for students' ability to ensure personal protection, data protection, safe and sustainable use of technology. The results from the Survey of Adult Skills (PIAAC) show that good reading proficiency "can ease the use of ICT for retrieving and using information, while frequent ICT use may contribute to improving or at least maintaining literacy abilities" (p. 21) [32]. Students' reading skills and proficiency can strengthen and develop their digital competence [33]. For example, adolescents must consider and accept the terms of use when they use photos from an online photo archive and when they copy or rephrase words from online resource. These terms and conditions are often provided through comprehensive and long texts written with legal formulations. Reading proficiency and comprehension can therefore play a role in students' Internet safety awareness and understanding.

\subsection{Research Questions and Hypotheses}

The aim of this study is to identify and understand Internet safety awareness among upper secondary school students in a school context, aged 15 or 16, and to examine the importance, for example, of social background on their Internet safety awareness and responsibility. Several examples from previous research shows how social background (such as number of books and language at home, academic aspirations and reading comprehension) can explain variations in digital competence in general and in more specific areas such as Internet safety [26,30,34]. These factors are illustrated in Figure 1.

Figure 1. Illustrations of factors predicting Internet safety.



Four hypotheses have been developed:

- H1: Students' cultural capital predicts their Internet safety;

- H2: Language integration at home predicts Internet safety;

- H3: Academic aspirations predict Internet safety;

- H4: Reading proficiency predicts Internet safety. 


\section{Methodology}

A cross-sectional assessment was conducted in 23 upper secondary schools from a large Norwegian municipality. The survey was carried out using an online assessment tool with multiple-choice questions, matrix questions and combined questions. This test was initiated and administrated by the local municipality. The schools were responsible for setting aside time for testing and ensuring that all students had the option to take the test. This is a formative assessment, and the student's performance did not have any consequences for their marks.

\subsection{Sample}

A total of 4230 students were tested at the beginning of their first semester in 2011 . However, 14 answers were excluded from the analysis because information was missing. Finally, the analyses were run on 4216 students, $53 \%$ boys and $47 \%$ girls, from 23 upper secondary schools and 238 classrooms. The number of students attending the schools varies from 30 students to 277 students. The average school consisted of 183.3 students, and the average classroom of 17.8 students. Overall, the data in the survey included $82.5 \%$ of the 5100 students enrolled in upper secondary school year 1 , in this specific municipality.

\subsection{Questionnaire and Instruments}

When developing questions and tasks for the assessment, we based the concept of Internet safety on the description of digital competence from the national curriculum. Several of the competence aims are vague and leave room for interpretation from teachers and school leaders' discretion. We therefore reviewed and analyzed the competence aims in the curriculum alongside school administrators, teachers and experts working for the municipality. We tried to ensure that our understanding of the competence aims were in line both with the intentions of the curriculum as well as how teachers and school administrators operationalized the curriculum.

Two different types of tasks were used to measure Internet safety: multiple-choice questions and tasks with subcomponents, i.e., two or three questions. Automatic scoring of the answers was part of the test. Correct answers to the multiple-choice questions were given 1 point, and incorrect answers were given 0 point. In order to obtain 1 point on the combined questions, all the questions had to be correct.

All the 20 items used to measure Internet safety are presented in Table 1. There are questions about how to protect and remove online information about yourself, and how to protect other people. The test has questions about how to deal with online bullying and threats, and how to use images and photos online.

In the Norwegian school system, students must choose between twelve different study programs when entering upper secondary school: three programs for general studies and nine programs for vocational education. The vocational education programs consist of two years of theory and two years of vocational practice. The programs for general studies extend for three years and prepare the students for higher education. The students were asked which study programs they attended. This information was recoded and used as an indicator of academic aspirations. The students' answers were coded with $0=\mathrm{a}$ study program for vocational education, or with 1 = a study program for general studies. 
Table 1. Test Items Measuring Internet Safety: Item difficulty (p-value) and correlation with the Total Score (discrimination).

\begin{tabular}{clcc}
\hline $\mathbf{N r}$ & \multicolumn{1}{c}{ Questions } & $\boldsymbol{p}$-value & Discrimination \\
\hline 1 & Why is it important to log out of a Learning Management System when you are done? & 0.96 & 0.16 \\
2 & You met "Girl17" online. Can you know for sure that she is a girl aged 17? & 0.96 & 0.41 \\
3 & When downloading a picture from the Internet, can a virus attack your digital device? & 0.66 & 0.33 \\
4 & Is it ok that you spread a rumor about other people online? & 0.90 & 0.45 \\
5 & What does it mean that your email is encrypted? & 0.61 & 0.42 \\
6 & Can you delete a photo posted on the Internet? & 0.80 & 0.53 \\
7 & Can other people identify the pages you have visited and the keywords used online? & 0.60 & 0.49 \\
8 & What is the BEST way to help a friend to publish photos online? & 0.85 & 0.52 \\
9 & How can anyone misuse your identify online? & 0.61 & 0.41 \\
10 & What is phishing? & 0.69 & 0.53 \\
11 & Is it ok that you tell personal information online? & 0.88 & 0.54 \\
12 & Is it ok that you post photos of others online? & 0.74 & 0.53 \\
13 & Who owns the photos posted in your profile on Facebook? & 0.25 & 0.23 \\
14 & Why is thirteen years old the minimum age on Facebook? & 0.91 & 0.60 \\
15 & You regret an e-mail you sent. Can you recall the e-mail? & 0.89 & 0.60 \\
16 & Is it right to send text messages that contain threatening content? & 0.62 & 0.40 \\
17 & What do you do with a text message that contains threatening content? & 0.79 & 0.59 \\
18 & What is the right thing to do if you want to delete photos posted online? & 0.75 & 0.45 \\
19 & What is the right thing to do with the online threats? & 0.78 & 0.57 \\
20 & What is the right thing to do about posting photos of others online? & 0.80 & 0.54 \\
\hline
\end{tabular}

$p$-value $=$ Difficulty of task. Discrimination $=$ Correlation with total score. All items from number 1 to number 15 are multiple-choice questions with one correct option. Item 16 have several correct options. The items from 17 to 20 are tasks with subcomponents i.e., two or three questions on each task.

The student's social background was measured with two questions. First, as a measure of language integration, the students were asked what language they spoke at home. Three options were given: 1 = Norwegian (the official language in all the 23 schools), 2 = Norwegian and another language, $3=$ only a language other than Norwegian.

Second, we used the number of books in the homes of the students as a proxy of cultural capital [35]. The scale (ranging from $0=$ no books, $1=1-10$ books, $2=11-50$ books, $3=51-100$ books, $4=101-250$ books, $5=251-500$ books, to $6=501$ books or more) was considered as an interval scale for the concept of cultural capital.

Information about the schools' proficiency levels in reading was based on a reading test carried out by the municipality. The reading test contained both a reading component and an understanding words component. We did not have access to the individual reading proficiency scores. Nevertheless, for each school, the municipality published information about the share of students on or below a critical threshold in reading proficiency. We computed a reading profile for each school by calculating the share of students above the critical threshold in reading.

In addition, gender, boys (0) and girls (1), was used as a background variable. 


\section{Results}

The data were analyzed by using the IBM SPSS version 21.

\subsection{Descriptive Data}

The majority of the students, $57 \%$, answered that they spoke only Norwegian language at home. Further 35.8\% spoke Norwegian and another language at home, and 7.2\% spoke only another language at home.

In the sample, $12.4 \%$ of the students report to having 10 or fewer books at home, $16.1 \%$ reported to having between 11 and 50 books at home, 23\% reported to having between 51 and 100 books, but $48.5 \%$ of the students had more than 100 books at home.

We found that $32.4 \%$ of the students are attending a vocational education program, whereas $67.6 \%$ of the students are attending a study program for general studies.

\subsection{Results from the Assessment}

Classical Test Theory concentrates on measuring the difficulty of a task, the discrimination of the items $[36,37]$ and the concept validity. Concept validity means that the items are in alignment with the competence goals mentioning Internet safety issues in the curriculum.

The $p$-value of the tasks can be used as an indicator of a Difficulty Index (DI). A high level on the p-value indicates an easy task, for instance, $p=0.70$ means that $70 \%$ of the students answered correctly. On the other hand, a low level of $p$-value indicates a more difficult task, for instance, $p=0.25$. There are no absolute values for difficulty [36], but there are recommendations. McAlpine suggests that acceptable values of $p$-value are lower than 0.85 and higher than 0.15 [37]. However, a $p$-value $=0.5$ contributes more to measurement than the $p$-values further away from 0.5 .

Discrimination is about whether those who succeed with a task are also successful with the rest of the tasks on the test. The discrimination is measured by the correlation between each item and the total score of the test. According to literature, values of DC $>0.20$ are acceptable; however, values of DC $>0.40$ are desirable [37,38].

Table 1 contains the $\mathrm{p}$-values and the discrimination of all the 20 items from the quiz. When it comes to $p$-value, item 13 has a $p$-value $=0.25$, meaning that $25 \%$ of the students were able to answer the item correctly. However, the remaining 19 items have $p$-values from $p=0.60$ and above. Table 2 provides an overview of the frequency of $p$-values for the 20 items. Table 2 shows that $30 \%$ of the items have $p$-values between 0.60 and 0.69 , whereas $30 \%$ of the items have $p$-values between 0.70 and 0.80 . The findings reveal that $35 \%$ of the items have $p$-values above 0.80 . Overall, six of the items have a $p$-value above 0.85 , and these need to be scrutinized and revised for further studies.

When it comes to the discrimination values, Table 1 show that 19 of the 20 items have acceptable levels of discrimination; item correlation with total score above 0.20 . Item 1 has a lower level of discrimination, as the correlation between item 1 and the total score of all items is 0.16 .

When it comes to the measuring the concept of Internet safety, all questions are mapped to the competence aims in the curriculum for students entering upper secondary school. Furthermore, 
Cronbach's alpha $=0.80$, which indicates a good internal consistency of the 20 questions used to measure Internet safety.

Table 2. Distribution of Gender, Cultural Capital, Language at Home, Academic Aspirations and Item Difficulty.

\begin{tabular}{llc}
\hline \multicolumn{1}{c}{ Variables } & \multicolumn{1}{c}{ Labels } & Frequency \\
\hline \multirow{2}{*}{ Gender } & Boys & $53.0 \%$ \\
& Girls & $47.0 \%$ \\
\hline \multirow{3}{*}{ Cultural capital } & $0-10$ books & $12.4 \%$ \\
& $11-50$ books & $16.1 \%$ \\
& $51-100$ books & $23.0 \%$ \\
& $101-250$ books & $16.2 \%$ \\
& More than 250 books & $32.3 \%$ \\
\hline \multirow{2}{*}{ Language at home } & Norwegian & $57.0 \%$ \\
& Norwegian and another language & $35.8 \%$ \\
\multirow{2}{*}{ Academic aspirations } & A language other than Norwegian & $7.2 \%$ \\
\hline \multirow{3}{*}{ Item difficulty (20 items) } & Vocational training & $32.4 \%$ \\
& General studies & $67.6 \%$ \\
\hline & $p$-value below 0.60 & $5 \%$ \\
& $p$-value between 0.60 and 0.69 & $30 \%$ \\
& $p$-value between 0.70 and 0.80 & $30 \%$ \\
& $p$-value above 0.80 & $35 \%$ \\
\hline
\end{tabular}

The total score from the assessment of Internet safety awareness shows that the overall difficulty of the Internet safety test was $p=0.75$. The average score was $15.06(S D=3.64)$. The schools with the highest score have an average score of 17.14 points, whereas the schools with the lowest score have an average score of 11.63 points. This difference in scores is 5.51 points and this difference represents 1.51 $S D$ from the highest to the lowest scoring school.

The results from the reading proficiency test were presented with the share of students from each school above a critical threshold. The average score was $80 \%$ above the critical threshold $(S D=13.45)$. The schools with the highest share of students had $97 \%$ above the critical threshold and the schools with the lowest share of students had $44 \%$ above the critical threshold.

\subsection{Correlations}

The Internet safety awareness score (in Table 3 ) has a positive correlation with language at home $(r=0.35, p<0.001)$, with books at home $(r=0.35, p<0.001)$ and academic aspirations $(r=0.27$, $p<0.001)$. Regression analysis was used to measure the correlation between Internet safety and reading proficiency $(r=0.40, p<0.001)$. Finally, Internet safety and gender has a positive, weak correlation $(r=0.09, p<0.05)$. 
Table 3. Bivariate Correlation between Internet Safety, Cultural Capital, Language at home, Gender (Control Variable), Academic Aspirations and Reading Proficiency (measured with regression analysis).

\begin{tabular}{lcccccc}
\hline \multicolumn{1}{c}{ Variables } & $\mathbf{1}$ & $\mathbf{2}$ & $\mathbf{3}$ & $\mathbf{4}$ & $\mathbf{5}$ & $\mathbf{6}$ \\
\hline 1. Internet safety & 1 & & & & & \\
2. Language at home & $0.35^{* *}$ & 1 & & & & \\
3. Cultural capital & $0.35^{* *}$ & $0.44^{* *}$ & 1 & & & \\
4. Academic aspirations & $0.27^{* *}$ & $0.09^{* *}$ & $0.29 * *$ & 1 & & \\
5. Gender & $0.09 * *$ & $0.06^{* *}$ & $0.08^{* *}$ & $0.09 * *$ & 1 & \\
6. Reading proficiency & $0.40 * *$ & $0.30^{* *}$ & $0.41^{* *}$ & $0.52 * *$ & $0.06 * *$ & 1 \\
\hline \multicolumn{7}{c}{$* * 0.01}$. \\
\end{tabular}

\subsection{Multilevel Analysis}

Multilevel analysis is a method to answer research questions when students are nested in schools or classrooms. All students are nested within classrooms, and all classrooms are nested within schools. Students represent level 1, classrooms represent level 2 and schools represent level 3.

Different models are run in the multilevel analysis using the Mixed Models procedure of IBM SPSS. The "empty model" consists only of the dependent variable: Internet safety (Table 4). The proportions of variance in Internet safety accounted for by schools and classrooms are calculated. An interclass correlation is run. The analysis demonstrates that $16.93 \%$ of the variance is attributed to differences between schools, $14.87 \%$ of the variance can be attributed to differences between classrooms, and the residual accounts for $68.19 \%$ of the variance.

Table 4. Results from Multilevel Analysis with Internet Safety as Dependent Variables and Cultural Capital, Language Integration at Home, Gender (Control Variable), Academic Aspirations and Reading Proficiency as Independent Variables.

\begin{tabular}{|c|c|c|c|}
\hline & $\begin{array}{c}\text { Model 0 } \\
\text { Coefficient (SE) }\end{array}$ & $\begin{array}{c}\text { Model 1 } \\
\text { Coefficient (SE) } \\
\end{array}$ & $\begin{array}{c}\text { Model 2 } \\
\text { Coefficient (SE) }\end{array}$ \\
\hline \multicolumn{4}{|l|}{ FIXED EFFECTS } \\
\hline Constant & $14.77 * *(0.34)$ & $15.14 * *(0.29)$ & $14.69 * *(0.24)$ \\
\hline Gender $($ boys $=0$, girls $=1)$ & & $0.27 * *(0.10)$ & $0.26 *(0.10)$ \\
\hline Languages other than Norwegian at home & & $-1.68 * *(0.19)$ & $-1.68 * *(0.20)$ \\
\hline Norwegian and other languages at home & & $-1.60 * *(0.11)$ & $-1.61 * *(0.11)$ \\
\hline Mainly Norwegian language at home & & - & - \\
\hline Cultural capital & & $0.26 * *(0.04)$ & $0.24 * *(0.04)$ \\
\hline Academic aspirations & & & $0.94 * *(0.23)$ \\
\hline Reading proficiency & & & $0.06 *(0.01)$ \\
\hline \multicolumn{4}{|l|}{ COVARIANCE ESTIMATES } \\
\hline Residual & $9.25 * *(0.21)$ & $8.57 * *(0.19)$ & $8.57 * *(0.19)$ \\
\hline Intercept (classroom level) & $2.02 *(0.27)$ & $1.55 * *(0.22)$ & $1.40 * *(0.20)$ \\
\hline Intercept (school level) & $2.30 *(0.77)$ & $1.22 * *(0.44)$ & $0.14 * *(0.28)$ \\
\hline Model fit: -2 LL & 21754 & 21387 & 21337 \\
\hline Decrease in $-2 \mathrm{LL}$ & & $48 * *$ & $50 * *$ \\
\hline
\end{tabular}




\subsubsection{Model 1}

Language integration and cultural capital are added to the fixed part of Model 1. Students' language integration is entered as a dichotomous variable in the analysis (the baseline is only Norwegian language at home). The results, presented in Table 4, show that the estimated coefficients for language integration and cultural capital are significant $(p<0.01)$. Additionally, the fit of the model was measured using the -2 Log Likelihood estimation ( -2 LL). Model improvement by moving from Model 0 to Model 1 was significant.

\subsubsection{Model 2}

In Model 2, academic aspirations and reading proficiency are added to the factors in Model 1. Model improvement, measured with -2 LL, shows that Model 2 has a better fit compared with the other models.

The results in Table 4 show that the estimated coefficients for all the independent variables have a significant relation to Internet safety $(p<0.01)$. Overall, all the four hypotheses in the study are supported.

The consequence of entering cultural capital, language integration, academic aspirations and reading proficiency into the regression equation is that the between-schools variance decreases by $93.75 \%$ (from 2.30 to 0.14 ), the between-classroom variance decreases by $30.59 \%$ (from 2.02 to 1.40 ) and the between-students variance decreases by $7.38 \%$ (from 9.25 to 8.57 ).

\subsubsection{Correlating Aggregated Results on School Level}

The findings from the multilevel analysis show that a considerable amount of the variation between the schools can be explained by the analysis. In order to look further into the school level, data is aggregated with the school as the analytical unit.

The correlations between Internet safety awareness, cultural capital, language integration and reading proficiency on the school level show high Pearson's $r$ (Table 5). When looking at the relationship between reading proficiency and social background, a regression analysis $\left(r=0.91, R^{2}=0.81, p<0.01\right)$ on the school level shows that cultural capital explains $81 \%$ of the variation in reading proficiency scores on the school level.

Table 5. Bivariate Correlation between Internet Safety, Reading Proficiency, Cultural capital, Language at Home and Academic Aspirations ( $n=23$ upper secondary schools).

\begin{tabular}{lccccc}
\hline \multicolumn{1}{c}{ Variables } & $\mathbf{1}$ & $\mathbf{2}$ & $\mathbf{3}$ & $\mathbf{4}$ & $\mathbf{5}$ \\
\hline 1. Internet safety & 1 & & & & \\
2. Reading proficiency & $0.92 * *$ & 1 & & & \\
3. Cultural capital & $0.90 * *$ & $0.90 * *$ & 1 & & \\
4. Language at home & $0.84 * *$ & $0.88^{* *}$ & $0.93 * *$ & 1 & \\
5. Academic aspirations & $0.73 * *$ & $0.80 * *$ & $0.79 * *$ & $0.67 * *$ & 1 \\
\hline \multicolumn{7}{c}{$* 0.01}$. & &
\end{tabular}


The results presented in Table 5 also show that Internet safety on the school level has a strong positive correlation with cultural capital $(r=0.9, p<0.01)$, language integration $(r=0.84, p<0.01)$, academic aspirations $(r=0.73, p<0.01)$ and reading proficiency $(r=0.92, p<0.01)$.

\section{Discussion}

Since 2009 most Norwegian upper secondary schools have provided personal laptops or tablets to each student. The purpose is that teachers and students use ICT as part of lessons and schoolwork, for learning purposes. However, this makes demands on students' knowledge and understanding of privacy, copyright and security. Gaining access to technology does not necessarily give students the competence and ethical awareness needed in order to behave responsibly and correctly online. The purpose of this paper is to gain knowledge of conditions related to students' Internet safety awareness, as an impact of access to technology.

Research questions and hypotheses have been formulated to scrutinize factors predicting students' level of Internet safety awareness. Four hypotheses are tested with a multilevel analysis. The results from the multilevel analysis reveal that Model 2 has a better fit compared with the other models. The overall variance decreases significantly when cultural capital, language integration, gender (control variable), academic aspirations and reading proficiency are entered into the regression equation. Overall, the results indicate variation in students' level of Internet safety, and the results from Model 2 show that the data material confirms all four hypotheses.

The first two hypotheses address students' social background, measured by cultural capital and language integration, and the analysis shows that cultural capital and language integration have positive impacts on students' level of Internet safety. This finding indicates the presence of social inequality in awareness of Internet safety, and that students' social background plays a role. This result is in line with other studies, which also explain the digital divide among students by their social background, here, language integration and cultural capital. According to findings from the EU kids online project [29,38], social background plays an important role in children's online activities and can explain variation in risk activities. Children with a low SES background are more likely to get into risky situations that may lead to harm than children from families with high SES. Children from homes with little or no access to technology often lack the skills to deal with potentially harmful situations, as a high level of Internet safety comes from the practice and use of technology. Most children in Norway have extensive experience with technology by the time they start school. Nonetheless, as Staksrud argues [38], there is reason to be concerned about the group of children with little or no access to technology, those who come from a home with low SES. As these children are already lagging far behind their fellow students, and are poorly equipped with skills on how to manage challenges or risky situations, they end up by reinforcing their dispositions [38]. This shows why it is crucial for the school to take an active part in raising students' Internet safety awareness. It is the responsibility of the school to help even out differences in skills and reduce the gap of the digital divide, to ensure all children have the same possibilities and opportunities, regardless of their predispositions. Valcke et al. (2007) [39] refers to research that reveals parents' expectations for schools to play a central role in developing safe Internet behavior in their children. As to the importance of supervision by parents, they [39] found clear evidence that parents have an impact on the safe Internet behavior of their children. However, as we know, not all 
students have supporting parents with sufficient knowledge of safe Internet use, so therefore the school plays an even more important role in evening out differences and divides among students.

Gender was also part of the analysis of social background used as a control variable in Model 1. There are no gender differences in Internet safety awareness when gender is entered into the equation together with social background. Although there are few differences in boys' and girls' reporting of overall experiences online that have bothered them in some way, girls are more likely to feel upset by the risk they encounter [28]. According to Valcke et al. [40] researchers often underpin the role of gender and age when studying differences in Internet usage. Traditionally, girls 'use the Internet significantly more for social networking or communication while boys tend to focus more on games and entertainment-related activities (p. 1293) [40].

The third hypothesis on academic aspirations is examined and supported. The results from the analysis show that students attending programs for general studies performed better than students attending vocational programs. This is in line with results from other studies [11,30]. Over time, the differences between academic aspirations can lead to inequalities and differences between people related to the professions and careers they pursue.

The fourth hypothesis about reading proficiency on school level is supported. The results show that on average, students from schools with higher levels of reading proficiency are scoring higher on Internet safety awareness compared to students from schools with lower levels of reading proficiency. This is in line with the international PIAAC study emphasizing the importance of reading when it comes to students' ability to use ICT in a responsible way [32].

Overall, the analyses reveal differences in students' competence and skills in the Internet safety field due to social differences. We believe schools in general and teachers in particular can be important contributors in equalizing these differences and divides among students.

The analysis reveals significant differences between both schools and classrooms participating in the study, from the same municipality. It seems that competent and confident teachers, in schools with a systematic approach to teaching Internet safety, have a key role when it comes to developing students' Internet safety awareness. As we have discussed in this paper, students come into school with varied backgrounds, foundations and understandings brought with them from home, and these variations in cultural, social and academic capital can to a large extent explain the variation in competence. With this in mind, we believe priorities should be made in order to ensure all students have access, at school, to high quality training opportunities in Internet safety in general, and Internet safety measures in particular.

\section{Concluding Remarks}

In summing up the results from the study of students' Internet safety awareness, we found differences on various levels both between schools and between classrooms. This is not in accordance with the vision behind the Norwegian school policy of avoiding inequalities between schools, classrooms and students.

The level of Internet safety awareness seems to be quite varied among students. The results show that we cannot treat this group of students as a uniform group, because there is variation in their levels of proficiency. One implication of these results is to be careful with assuming that all students are able to familiarize themselves with the topic of Internet safety. 
Until recently, we know of few attempts to measure Norwegian students' Internet safety awareness. However, as schools and teachers map what students know and are able to do, schools become more able to make the correct decisions about how to fight digital divides and to attain digital inclusion. On the basis that there is a gap between school aims and school results, it is necessary for schools to start working more consciously with Internet safety awareness. The empirical findings in this study show variation between schools due to the students' social background. How to deal with this? In Norway, several attempts have been made to level out the gaps in students' competence. One example is working towards schools and families, by giving information and guidance on how to be good role models, and how to teach Internet safety to young people. Internet safety is about raising awareness, developing sound and good attitudes, which will in turn lead to good actions.

Overall, the findings show variation between schools, due to the students' social background, their academic aspirations and the schools' level of reading proficiency. Previous research indicate the importance of social background [9,22,24,25,27,33,34,41,42] and academic aspirations [11,30] on students' ability to understand and use technology. Developing material for adult caretakers is one way to reach the students' families; however, there is concern about how to reach and impact less privileged parents. This concern needs to be further examined and addressed. Material should be related to the competence aims and developed for schools, in order to motivate teachers to make use of available resources, for example, dubestemmer.no. [43] However, as the use of such resources is optional, the schools have to be willing to use them, and school leaders must make priorities and put pressure on the teachers to actually use the available resources.

Finally, the variations between classrooms indicate that teachers play an important role in students' understanding of Internet safety issues. The teachers and the schools are responsible for providing students with the opportunity to reach and meet the competence aims during lessons and homework, and to ensure that all students, regardless of background, have the same potential of being safe and responsible online.

\section{Acknowledgments}

The authors would like to thank their colleagues and project partners.

\section{Author Contributions}

All authors worked extensively together to conceive the work presented in this manuscript and were involved in its preparation.

\section{Conflicts of Interest}

The authors declare no conflict of interest.

\section{References}

1. European Commission. Survey of Schools: ICT in Education; The European Union: Luxembourg, 2013. 
2. Krumsvik, R.J.; Ludvigsen, K.; Urke, H.B. Klasseleiing og IKT i Vidaregåande Opplaering; DLC-rapport nr.1/2011; Universitetet i Bergen: Bergen, Norway, 2011.

3. Heck, R.H. Multilevel modeling with SEM. In New Developments and Techniques in Structural Equation Modeling; Marcolides, G.A., Schumacker, R.E., Eds.; Taylor and Francis: Mahwah, NJ, USA, 2009; pp. 89-126.

4. Bickel, R. Multilevel Analysis for Applied Research: It's Just Regression! The Guilford Press: New York, NY USA, 2007.

5. Livingstone, S.; Hasebrink, U.; Garitaonandia, C.; Garmendia, M. Comparing online risks faced by European children: Reflections on youthful Internet use in Britain, Germany and Spain. Quaderns del CAC 2008, 31-32, 95-105.

6. Livingstone, S.; Ólafsson, K.; O’Neill, B.; Donoso, A. Towards a Better Internet for Children; London School of Economics: London, UK, 2012.

7. Ferrari, A. DIGICOMP: A Framework for Developing and Understanding Digital Competence in Europe; Joint Research Centre, Institute for Prospective Technological Studies, European Commission: Luxembourg, 2013.

8. Ferrari, A. Digital Competence in Practice: An Analysis of Frameworks; Joint Research Centre, Institute for Prospective Technological Studies, European Commission: Luxembourg, 2012.

9. International Society for Technology in Education (ISTE). The National Educational Technology Standards for Students. 1998. Available online: http://www.iste.org/standards.aspx (accessed on 15 March 2014).

10. Binkley, M.; Erstad, E.; Herman, J.; Raizen, S.; Ripley, M.; Miller-Ricci, M.; Rumble, M. Defining 21st century skills. In Assessment and Teaching of the 21st Century Skills; Griffin, P., McGaw, B., Care, E., Eds.; Springer: Dordrecht, The Netherlands, 2012.

11. Calvani, A.; Fini, A.; Ranieri, M.; Picci, P. Are young generations in secondary school digitally competent? A study on Italian teenagers. Comput. Educ. 2012, 58, 797-807.

12. The Norwegian Directorate for Education and Training. Framework for basic skills. Oslo: The Norwegian Directorate for Education and Training, 2013. Available online: http://www.udir.no (accessed on 20 May 2014).

13. The Norwegian Ministry of Education and Research. The Knowledge Promotion Reform. Available online: http://www.regjeringen.no/nb/dep/kd/tema/grunnopplaring/kunnskapsloeftet.html?id=1411 (accessed on 10 April 2014).

14. The Norwegian Directorate for Education and Training. Subject and curriculum. 2006. Available online: http://www.udir.no/Lareplaner/Grep/ (accessed on 10 May 2014).

15. Erstad, O. Changing Assessment Practice and the Role of IT. In International Handbook of Information Technology in Primary and Secondary Education; Voogt, J., Knezek, G., Eds.; Springer: New York, NY, USA, 2008; Part 1, pp. 181-194.

16. Søby, M.; Egeberg, G. Norway Country Report on ICT in Education; European Schoolnet: Brussels, Belgium, 2010.

17. Norwegian Directorate for Education and Training. Curriculum in Norwegian Subject. Available online: http://www.udir.no/Upload/larerplaner/Fastsatte_lareplaner_for_Kunnskapsloeftet/ english/5/Norwegian_subject_curriculum.doc (accessed on 15 March 2014). 
18. Norwegian Directorate for Education and Training. Curriculum in English Subject. Available online: http://www.udir.no/k106/ENG1-03/Hele/?lplang=eng (accessed on 15 March 2014).

19. Norwegian Directorate for Education and Training. Curriculum in Social Science Subject. Available online: http://www.udir.no/Upload/larerplaner/Fastsatte_lareplaner_for_Kunnskapsloeftet/english/5/ Social_studies_subject_curriculum.doc (accessed on 15 March 2014).

20. Center for Educational Research and Innovation \& Organization of Economic Co-operation and Development (CERI/OECD). Are the new Millennium learners making the grade? In Technology Use and Educational Performance in PISA; CERI/OECD: Paris, France, 2010.

21. Erstad, O. Educating the Digital Generation. Nord. J. Digit. Lit. 2010, 1, 56-70.

22. Selwyn, N. Challenging educational expectations of the social web: A Web 2.0 far? Nord. J. Digit. Lit. 2009, 4, 72-85.

23. Warschauer, M. Reconceptualizing the Digital Divide. Available online: http://firstmonday.org/ article/view/967/888 (accessed on 15 April 2014).

24. Pedró, F. The New Millennium Learners: Challenging Our Views on Digital Technologies and Learning. Nord. J. Digit. Lit. 2007, 4, 43-60.

25. Ministerial Council for Education, Early Childhood Development and Youth Affairs (MCEECDYA). National Assessment Program. ICT Literacy Years 6 and 10 Report 2008. Available online: http://www.mceecdya.edu.au/verve/_resources/NAP-ICTL_report_2008.pdf (accessed on 29 February 2014).

26. Organization of Economic Co-operation and Development (OECD). PISA 2009 Results: Students on Line Digital Technologies and Performance; OECD: Paris, France, 2011; Volume VI.

27. Zhang, G.; Wang, Q.; Kolodinsky, J. From access to usage: The divide of self-reported digital skills among adolescents. Comput. Educ. 2010, 56, 736-746.

28. Livingstone, S.; Görzig, A.; Ólafsson, K. Disadvantaged Children and Online Risk. EU Kids Online Network, London, UK Report. Available online: http://eprints.lse.ac.uk/39385/ (accessed on 25 April 2014).

29. Livingstone, S.; Haddon, L.; Görzig, A.; Ólafsson, K. Risks and Safety on the Internet: The Perspective of European Children Full Findings; London School of Economics: London, UK, 2011.

30. Hatlevik, O.E. Examining Digital Divide' in Upper Secondary School: A Multilevel Analysis of Factors with an Influence on Digital Competence. Int. J. Technol. Knowl. Soc. 2010, 6, 151-164.

31. Hatlevik, O.E.; Christophersen, K.S. Digital Competence in the beginning of upper secondary school: Digital inclusion. Comput. Educ. 2013, 63, 240-247.

32. European Commission. Education and Training Monitor 2013; The European Union: Luxembourg, 2013.

33. Frønes, T.S.; Narvhus, E.K.; Jetne, Ø. Students on the Internet. Digital reading in PISA 2009; Universitetet i Oslo: Oslo, Norway, 2011.

34. Claro, M.; Preiss, D.D.; Ernesto San Martín, E.; Jara, I.; Hinostroza, J.E.; Valenzuela, S.; Cortes, F.; Nussbaum, M. Assessment of the 21 st century ICT skills in Chile: Test design and results from high school level students. Comput. Educ. 2012, 59, 1042-1053.

35. Bourdieu, P.; Thompson, J.B. Language and Symbolic Power; Polity Press: Cambridge, UK, 1991.

36. Crocker, L.; Algina, J. Introduction to Classical and Modern Test Theory; Cengage Learning: Florence, KY, USA, 2006. 
37. McApline, H. A Summary of Methods of Item Analysis; University of Glasgow: Glasgow, UK, 2002.

38. Staksrud, E. Digital Mobbing; Universitetet i Oslo: Oslo, Norway, 2013.

39. Valcke, M.; Schellens, T.; van Keer, H.; Gerarts, M. Primary school children's safe and unsafe use of the Internet at home and at school: An exploratory study. Comput. Hum. Behav. 2007, 23, 2838-2850, doi:10.1016/j.chb.2006.05.008.

40. Valcke, M.; de Wever, V.; van Keer, H.; Schellens, T. Long-term study of safe Internet use of young children. Comput. Educ. 2011, 57, 1292-1305.

41. Boyd, D. It is Complicated; Yale University Press: London, UK, 2014.

42. Katz, I.R.; Macklin, A.S. Information and Communication Technology (ICT) Literacy: Integration and Assessment in Higher Education; Educational Testing Service: Princeton, NJ, USA, 2007.

43. Du bestemmer.no. Available online: http://www.dubestemmer.no/ (accessed on 15 March 2014).

(C) 2014 by the authors; licensee MDPI, Basel, Switzerland. This article is an open access article distributed under the terms and conditions of the Creative Commons Attribution license (http://creativecommons.org/licenses/by/4.0/). 